\title{
Menggaungkan Pendidikan Qawlan Ma'rufa sebagai Etika Pergaulan dalam Menyikapi Body Shaming
}

\author{
Saibatul Hamdi*, Hamidah Hamidah, \\ Aulia Mustika Ilmiani, Khabib Musthofa \\ Institut Agama Islam Negeri (IAIN) Palangka Raya, Indonesia \\ Jalan G.Obos Komplek Islamic Center, Kota Palangka Raya \\ Email: saibatul98.se@gmail.com
}

\begin{abstract}
The main problem of the research is the widespread trend of body shaming in the world of education which is contrary to social ethics in the Qur'an. The purpose of this study is to elaborate on the education of qawlan ma'rufa (kind words) to address body shaming by focusing on concept analysis and formulating solutions to be implemented in the field. The method used is qualitative with a concept analysis approach. The results of this study indicate that: first, the blurry portrait of body shaming has actually mushroomed and is worrying, so serious efforts are needed to overcome it. This fact is so contrary to the essence of social ethics, especially in the aspect of communication that must be applied. Second, qawlan ma'rufa education becomes an educational concept in good and appropriate communication that must be implemented in the association of students in schools/madrasas. The implementation of this concept is at least realized through family education and at school by strengthening moral education and polite culture. This study has implications for revitalizing the rise of social ethics and should be applied in various educational institutions today.
\end{abstract}

Keywords: Education, Social Ethic, Qawlan Ma'rufa, Body Shaming

Abstrak: Permasalahan utama penelitian adalah merebaknya tren body shaming di dunia pendidikan yang bertentangan dengan etika pergaulan dalam al-Qur'an. Tujuan dari penelitian ini adalah mengelaborasi pendidikan qawlan ma'rufa (perkataan yang baik) guna menyikapi body shaming dengan berfokus pada analisis konsep dan merumuskan solusi untuk diimplementasikan di lapangan. Metode yang digunakan adalah kualitatif dengan pendekatan analisis konsep. Hasil kajian ini menunjukkan bahwa: pertama, potret buram tindakan body shaming sejatinya telah menjamur dan mengkhawatirkan sehinga diperlukan upaya serius menggulanginya. Fakta ini begitu bertentangan dengan esensi etika pergaulan terutama dalam aspek komunikasi yang mesti diterapkan. Kedua, pendidikan qawlan ma'rufa menjadi sebuah konsep pendidikan dalam berkomunikasi yang baik dan pantas yang harus diimplementasikan dalam pergaulan peserta didik di sekolah/madrasah. Implementasi dari konsep ini setidaknya diwujudkan melalui pendidikan keluarga dan di sekolah dengan menguatkan pendidikan akhlak serta budaya santun. Kajian ini berimplikasi dalam merevitalisasi kebangkitan etika pergaulan dan hendaknya diterapkan di berbagai lembaga pendidikan saat ini.

Kata Kunci: Pendidikan, Etika Pergaulan, Qawlan Ma'rufa, Body Shaming

Jurnal Pendidikan Agama Islam Al-Thariqah Vol. 6, No. 1, Januari - Juni 2021

Received : 01 Mei 2021; Accepted : 07 Juni 2021; Published : 30 Juni 2021

*Corresponding Author : saibatul98.se@gmail.com 



\section{PENDAHULUAN}

Suatu keharusan yang tidak terelakkan adalah ketika setiap orang harus hidup bersosial, saling berinteraksi, membangun komunikasi, dan menjalin silaturahmi. Oleh karenanya setiap individu memerlukan orang lain untuk dapat menjalin interaksi sosial (Zuhri et al., 2020; Sukenti, and Tambak, 2019). Namun jalinan interaksi ini tidak serta merta berjalan begitu saja, melainkan harus berjalan dengan baik dan memperhatikan etika-etika yang ada sebagai upaya dalam menciptakan hubungan yang harmonis antar sesama (Idi, 2015; Ahmad, 2017, Tambak, 2010). Oleh karena itu, dalam pergaulan seharihari penting kiranya setiap tindakan yang dilakukan secara hati-hati dan mempertimbangkan baik buruknya.

Berbicara mengenai pergaulan, alQur'an telah memperingatkan untuk bertindak dengan perbuatan yang mulia. Allah SWT berfirman, "dan janganlah kamu panggil-memanggil dengan gelargelar yang buruk" (QS. Al-Hujurat: 11). Penggalan ayat dari al-Qur'an Surat AlHujurat tersebut telah mewanti-wanti tindakan manusia dalam bergaul. Hal ini merupakan tuntunan Islam untuk selalu menciptakan relasi yang indah tanpa harus menjelekkan atau menganggap buruk orang lain. Sebab akan ada banyak celah masalah yang akan menimpa jika manusia terus berkutat pada budaya yang tidak pantas sebagaimana terdapat pada zaman Jahiliyah silam (Wulandari, 2010; Al-Munawar, Tambak, and Kalsum, 2003).

Terkait hal ini, nilai-nilai akhlak yang tercermin dalam etika pergaulan amat penting digaungkan. Misi penting ini sejatinya menjadi tanggung jawab berbagai pihak yang meliputi keluarga, sekolah, dan masyarakat. Ibnul Qayyim dalam Arifin (2017) menjelaskan bahwa pendidikan akhlak amat penting diberikan sebagai jalan untuk membuat manusia itu terpuji. Umat-umat terdahulu telah memberi contoh pelajaran tentang pentingnya akhlak yang menentukan kemuliaan seseorang. Sebagai contoh kaum Luth yang bobrok tingkah lakunya hingga dilaknat oleh Allah SWT. Demikian bahwa akhlak begitu urgen diperhatikan terutama dalam persoalan pergaulan interaksi sesama manusia.

Namun dewasa ini, fenomena yang tidak mengenakkan semakin marak terjadi, salah satunya terkait dengan pergaulan yaitu fenomena body shaming. Body shaming merupakan perlakuan yang diterima oleh seseorang karena terdapat kekurangan pada dirinya yang dianggap negatif dan memalukan (Dolezal, 2015). Kekurangan yang dipandang negatif tersebut adalah mengenai bentuk atau bagian tubuh yang tidak sempurna. Sebagai contoh orang yang berbadan gemuk, terlalu kurus, terlalu tinggi atau terlalu pendek (Hidayat et al. 2019). Bahkan pada beberapa keadaan seperti yang pernah terjadi di Amerika, ukuran tubuh menjadi patologis dan penurunan berat badan didesak untuk mereka yang memiliki berat badan lebih tinggi. Hal ini memunculkan stigma negatif terhadap orang-orang yang mengalami obsesitas (Bombak et al., 2019; Ahmad, and Tambak, 2018).

Terdapat berbagai penelitian yang meneliti tentang body shaming di dunia pendidikan. Penelitian dari Studi Fit Rated kepada 1.000 orang laki-laki dan perempuan menyatakan bahwa 92,7\% perempuan pernah mengalami objek olokolok dikarenakan tampilannya. Adapun yang dialami oleh kaum pria sebanyak $86,5 \%$. Selain itu berdasarkan survei yang dilakukan body peace resolution yang dilaksanakan Yahoo! Health juga membuktikan bahwa perempuan lebih rentan dan banyak mendapat body shaming dibandingkan dengan laki-laki. Sasaran ditujukan untuk 2.000 orang dengan rentang usia 13-64 tahun ditemukan bahwa $94 \%$ remaja perempuan pernah mengalami body shaming, sementara remaja laki-laki sekitar 64\% (Hestianingsih, 2018). Selain itu, di sekolah juga terjadi, sebuah 
penelitian menyebut bahwa salah satu contoh kecilnya terjadi di SMPN 17 Kendari. Sejak 2018 hingga 2019 terjadi body shaming dengan berbagai motif seperti hanya guyonan, dendam, dam ketika melihat teman yang tidak mempunyai tubuh tidak ideal serta pendiam (Serni et al., 2020).

Penelitian dilakukan oleh Sakinah (2018) mengungkap bahwa body shaming dilakukan secara langsung maupun tidak langsung. Secara langsung misalnya berupa ejekan dengan gelar-gelar yang tidak mengenakkan seperti kutilang darat (kuris tinggi langsing dada rata) dan berbagai hinaan yang lain terhadap bentuk tubuh seseorang). Sedangkan yang tidak langsung berupa hujatan-hujatan di media sosial melalui kolom komentar. Cara untuk menghadapi body shaming adalah dengan menunjukkan kualitas diri, mengubah gaya atau penampilan, selalu berpikir kedepan dan positif, serta menghindari para pelaku body shaming.

Penelitian lain juga dikemukakan oleh Nasution and Simanjuntak (2020) mengenai pengaruh body shaming terhadap self-esteem pada siswa SMP. Hasil dari penelitian ini menunjukkan bahwa body shaming mempengaruhi selfesteem pada tingkatan sedang. Hasil pengujian uji-t menunjukkan bahwa thitung $>$ ttabel atau 3,887 > 2,001, dapat disimpulkan bahwa body shaming memiliki pengaruh secara signifikan terhadap tingkat self-esteem siswa di SMPN 2 Datuk Lima Puluh. Sementara berdasarkan penelitian lain juga membuktikan bahwa body shaming menurunkan tingkat kepercayaan diri, menjadi lebih sensitif, dan lebih berhatihati ketika menyangkut penampilan (Fauzia and Rahmiaji, 2019).

Penelitian selanjutnya oleh Muhajir (2019) mengemukakan bahwa citra tubuh yang indah tercipta dari budaya popular dan media massa yang kemudian dijadikan standar oleh banyak orang untuk menjadi kriteria tubuh yang ideal. Hal ini yang kemudian menjadikan seseorang melakukan body shaming terhadap orang lain dengan tujuan melampiaskan ekspresi penilainnya kepada orang lain. Akibatnya, mereka yang merasa tidak sesuai standar akan menurunkan kepercayaan dirinya dan kemudian mengubah penampilan fisik melalui konsumsi dan hal ini berdampak kepada budaya konsumtif yang kemudian memberi keuntungan terhadap ekonomi kapitalis.

Beberapa penelitian terdahulu yang telah dipaparkan di atas berupaya untuk mengungkap fenomena body shaming dan dampaknya sehingga perlu diatasi secara maksimal. Di antara solusi yang dihadirkan hanya berupa upaya represif ketika terjadi perlakuan body shaming. Kesamaan dengan penelitian ini adalah sama-sama menganalisis body shame dalam dunia pergaulan. Maka, solusi untuk mengatasi permasalahan ini melalui etika pergaulan dengan menekankan pendidikan qawlan ma'rufa. Penelitian ini merupakan hal baru yang belum pernah diteliti peneliti lain sebelumnya, dimana mengungkap etika pergaulan dengan pendidikan qawlan ma'rufa untuk mengatasi fakta body shaming melalui pendekatan pendidikan yang diadopsi dari konsep al-Qur'an dan kemudian menawarkan solusi preventif. Hal ini bertujuan untuk meminimalisir body shaming yang telah menjamur di masyarakat termasuk juga di dunia pendidikan. Penelitian sangat penting untuk pencegahan agar tidak tercipta pelaku-pelaku body shaming yang baru melalui pendekatan pendidikan qawlan ma'rufa dan penguatan pendidikan akhlak yang komprehensif.

Penelitian ini mengupas tuntas tentang spirit qawlan ma'rufa sebagai etika pergaulan yang terimplementasi dalam pendidikan guna menyikapi fenomena body shaming. Maka dirumuskan dua persoalan utama dalam penelitian ini yaitu; pertama membahas tentang temuan potret buram fenomena body shaming dalam pendidikan 
Indonesia. kedua, langkah dalam menggaungkan pendidikan qawlan ma'rufa sebagai etika dalam pergaulan untuk mengatasi body shaming berdasarkan ajaran Islam.

\section{KONSEP TEORI}

\section{Etika Pergaulan}

Jika mengkaji secara harfiah, etika dimaknai sebagai kriteria penilaian baik dan buruk yang terkait dengan akhlak. Adapun secara lebih luas, etika dimaknai sebagai suatu indikator untuk memberi keputusan dalam menilai sesuatu yang pantas dan tidak pantas di lingkungan masyarakat (Nurrahmi, et al., 2021; Tambak, 2019). Demikian bahwa etika akan selalu melekat dalam setiap aspek kehidupan sebagai sebuah aturan atau pedoman.

Dalam tatanan kehidupan sosial, etika menjadi sesuatu yang amat penting untuk diperhatikan. Etika menjadi pedoman atau acuan dalam bertingkah laku dan menjadi tolak ukur untuk menilai salah atau benarnya perbuatan yang dilakukan. Sebagai gambaran penting bahwa dalam agama Islam pun, Allah SWT mengutus Rasulullah sebagai figur pemberi contoh etika yang sempurna dengan segenap keteladanan yang dimiliki beliau. Hal ini menunjukkan bahwa segala aspek akan menjadi perhatian ketika etika dapat diterapkan (Kamil, 2021; Tambak, and Syafitri, 2016).

Terlebih dalam persoalan pergaulan, etika memegang peranan utama yang berfungsi dalam menyeleraskan hubungan yang harmoni. Sejatinya, etika pergaulan menempati beberapa fungsi penting sebagai beriku:

Pertama, etika pergaulan sebagai rambu-rambu. Sejatinya, etika memberikan panduan yang jelas tentang segala hal yang boleh atau tidak boleh untuk dilakukan. Begitu pula pada etika pergaulan amat penting untuk digaungkan mengingat etika ini menjadi rambu-rambu yang ampuh dalam menciptakan pergaulan yang sehat dan bermartabat.
Etika menjadi penting ketika manusia dihadapkan pada berbagai kondisi yang memerlukan pemahaman terhadap norma atau aturan-aturan yang berlaku. Sebab sejatinya pada setiap keadaan pun terdapat ketentuan-ketentuan yang semestinya untuk dipatuhi (Adisti, 2010). Etika berfungsi melebihi moral dan norma. Sebab etika lebih menekankan pada aksi atau perbuatan yang didasarkan pada moral dan norma yang ada. Oleh karenanya pada setiap keadaan etika amat penting diajarkan dan dikenalkan sebagai manifestasi dari nilai moral dan norma yang semestinya dipatuhi (Baiquni and Astuti, 2018; Tambak, and Sukenti. 2020). Maka sepatutnya etika selalu ditekankan pada hal-hal yang kecil seperti bergaul terhadap sesama. Terlebih qaulan ma'rufa menjadi salah satu bagian etika yang semestinya digaungkan guna menyikapi fenomena body shaming yang kian marak terjadi.

Kedua, etika pergaulan sebagai kebutuhan. Ada banyak pembahasan yang terkait etika dalam al-Qur'an, salah satunya disebutkan tentang al-aqrobin. AlQur'an melihat bahwa al-aqrobin adalah orang-orang yang terdekat, didasarkan pada hubungan darah ataupun tempat tinggal, semestinya dipedulikan seorang muslim. Menurut al-Qur'an, dalam menghadapi al-aqrobin ini diperlukan etika. Etika yang dimaksud adalah etika bermasyarakat yang terlihat pada tata tatanan pergaulan masyarakat dengan menjunjung tinggi sikap saling memahami dan mendukung satu sama lain (Fauzi, 2020; Sukenti, and Tambak, 2020). Benang merah yang dapat diambil adalah etika pergaulan menjadi sebuah kebutuhan dalam berkehidupan sosial sebagaimana anjuran Alquran tentang alaqrobin. Hal ini menggambarkan bahwa Islam begitu memperhatikan hubungan hablumminannas selain juga hablumminallah yang penting. Karena sejatinya manusia hidup berbaur satu sama lain, dan oleh sebab itu ukhuwah islamiyah menjadi pondasi yang harus 
dikokohkan guna membangun harmonisasi kehidupan yang indah. Salah satu ikhtiar yang dilakukan adalah dengan menghadirkan qawlan ma'rufa sebagai sebuah panduan dalam berkata sehingga dapat menurunkan tendensi fenomena bullying yang kian marak terjadi.

\section{Penentuan Etika dalam Islam}

Terkait dengan penentuan etika dalam Islam, para ulama sepakat bahwa tolak ukur menentukan perbautan baik atau buruk dalam Islam adalah berdasarkan apa yang terdapat di dalam al-Qur'an dengan segenap aturan yang semestinya dilaksanakan serta larangan yang harus ditinggalkan. Perbuatan baik dikatakan sebagai tahsin dan perbuatan buruk dikatakan sebagai taqbih (Fauzi, 2020).

Selain al-Qur'an, sumber etika dalam Islam adalah berasal dari Sunnah Nabi. Hal-hal yang telah disabdakan maupun dicontohkan oleh Rasulullah menjadi suatu pedoman dan etika dalam setiap tingkah laku. Sehingga akan terlihat jelas batasan-batasan yang perlu diperhatikan dalam bertindak dan penentu kategori baik atau buruk (Hardiono, 2020).

Namun pada dasarnya penentuan baik maupun buruk dalam Islam ditentukan oleh prinsip keadilan. Maksudnya adalah dalam menilai sesuatu, tidak serta merta yang terlihat salah adalah pasti salah, namun harus melihat konteks dan tujuan dari perbuatan yang terlihat salah tersebut. Bisa saja perbuatan yang pada awalnya salah bisa menjadi baik, atau sebaliknya. Begitu pun yang berlaku dalam etika pergaulan (Nilda and Aryantialfi, 2021).

\section{Qaulan Ma'rufa Sebagai Etika Pergaulan}

Secara bahasa, qawlan diartikan sebagai sebuah perkataan, sedangkan arti kata ma'ruf adalah baik dan dapat diterima oleh nilai-nilai yang berlaku dalam masyarakat. Maksud dari diterima oleh nilai-nilai di masyarakat adalah perkataan yang diucapkan merupakan perkataan yang lazim digunakan di lingkungan sang penutur. Apabila dilihat dari konteks ayat Alquran, penggunaan kata qaulan ma'rufa berada dalam konteks peminangan, pemberian wasiat, dan waris. Oleh karenanya, qawlan ma'rufa mengandung makna ujaran yang halus dan kebanyakan disukai oleh perempuan serta anak-anak, sehingga pantas diucapkan oleh pembicara dan orang yang diajak bicara (Sugiarti, 2020; Tambak, et al. 2020).

Kata qawlan ma'rufa yang banyak disebutkan di dalam ayat Alquran sejatinya memiliki makna yang begitu luas. Qawlan ma'rufa merupakan ucapan yang menyenangkan hati, mudah dimengerti, dan tidak menimbulkan kemarahan atau kesedihan orang lain. Salah satu penggunaan kata ini dalam Alquran adalah ketika Allah SWT berbicara tentang kewajiban orang-orang kaya atau orang kuat terhadap orangorang miskin atau lemah. Maka qawlan ma'rufa berarti juga pembicaraan yang bermanfaat, memberi tambahan pengetahuan, mencerahkan pemikiran, dan memberi pemecahan masalah (Aziz, 2019). Qawlan ma'rufa dijadikan sebagai salah satu bagian dari etika pergaulan. Hal ini karena qawlan ma'rufa sejatinya sebagai pegangan untuk bertutur kepada orang lain dalam dunia pergaulan. Sebab sejatinya etika pergaulan memiliki urgensi penting dalam tatanan kehidupan sosial (Siregar, 2021).

Secara lebih dalam, Muslimah (2016) menjelaskan bahwa terdapat dua implikasi dari qawlan ma'rufa adalah sebagai berikut:

Pertama, qawlan ma'rufa sebagai kata yang abstrak. Penerapan qawlan ma'rufa dalam berkomunikasi juga dapat dimaknai sebagai penggunaan kata yang abstrak ketika akan menggiring sebuah kebenaran, sehingga menimbulkan penafsiran yang berlainan dan menuntun orang lain secara tidak langsung mengikuti. Sebagai contoh ketika seorang 
da'i menyampaikan ceramahnya untuk lebih mengedepankan dalil daripada akal. Hal ini secara tidak langsung memberi sugesti kepada pendengar untuk lebih berhati-hati terhadap rasio.

Kedua, qawlan ma'rufa sebagai pengalihan bahasa yang halus. Pada beberapa keadaan, penggunaan kata-kata yang tidak tepat, terlalu vulgar, atau terlalu jelas juga seringkali menimbulkan kekacauan. Ada sifat-sifat manusia yang mudah tersinggung atau mudah tersakiti. Maka qawlan ma'rufa berfungsi dalam mengubah redaksi perkataan itu menjadi lebih pas, lebih santun, dan halus agar dapat diterima dengan mudah.

Berdasakan teori di atas diketahui bahwa qawlan ma'rufa merupakan perkataan yang pantas dan sesuai untuk diucapkan. Hal ini tentu sangat erat kaitannya dengan fenomena body shaming yang marak terjadi. Qawlan ma'rufa menjadi etika pergaulan menurut alQur'an yang dapat meredam fenomena ini. Urgensi penting ini sejatinya menjadi sebuah keharusan yang harus ada dalam setiap pergaulan. Nilai-nilai qawlan ma'rufa setidaknya dapat diimplementasikan pada hal-hal sederhana yang dilakukan dalam kehidupan sehari-hari. Oleh karenanya, qawlan ma'rufa menjadi rambu-rambu dalam bertindak dan sebuah kebutuhan yang senantiasa harus terpenuhi dalam pergaulan sesama. Misi penting ini juga menjadi urgen diterapkan dalam dunia pendidikan khususnya di sekolah untuk memberi pembiasaan kepada peserta didik guna menghadirkan perkataanperkataan yang baik dalam pergaulan sehari-hari.

\section{METODE PENELITIAN}

Jenis penelitian yang digunakan dalam penelitian ini kualitatif dengan pendekatan analisis konsep yang berupaya memusatkan perhatian pada konsep yang telah ada sebelumnya agar dapat dimengerti, dideskripsikan, dan diimplementasikan di lapangan
(Mardawani, 2020) tentang qawlan ma'rufa sebagai etika pergaulan dalam mengatasi body shaming. Adapun konsep yang akan dieksplor dalam penelitian ini adalah konsep pendidikan qawlan ma'rufa yang dapat diimplikasikan dalam meredam aksi body shaming khususnya di sekolah. Konsep ini digali dari ayat-ayat al-Qur'an melalui tafsir kemudian diperkuat dengan referensi pendukung seperti buku dan jurnal hasil penelitian untuk menemukan sebuah konsep baru yang dapat dilaksanakan di lapangan.

Sumber data dalam penelitian ini terbagi menjadi dua, yaitu primer dan sekunder. Sumber data primer adalah berasal dari ayat-ayat tentang qawlan ma'rufa beserta tafsirnya, sedangkan sumber sekunder berasal dari buku, jurnal ilmiah, dan artikel-artikel berita sebagai pendukung dan juga sumber data untuk temuan body shaming. Pengumpulan data dilakukan dengan menggali informasi seputar data body shaming dan ayat-ayat tentang qaulan ma'rufa sebagai solusi. Adapun teknik analisis data menggunakan analisis konten atau isi dan menggunakan pendekatan tafsir maudhu'i yakni dengan mengumpulkan ayat al-Qur'an berdasarkan tema-tema tertentu kemudian dilakukan analisis secara mendalam dan memperoleh korelasi antar ayat tersebut secara komprehensif (Izzan, 2011). Maka dalam penelitian dibahas adalah ayat-ayat yang berbicara mengenai qawlan ma'rufa yang dijelaskan melalui beberapa tafsir dan kemudian ditarik korelasi dan kesimpulan yang memunculkan sebuah konsep real yang dapat diterapkan khususnya di lembaga pendidikan seperti sekolah atau madrasah.

\section{HASIL DAN PEMBAHASAN \\ Fenomena Body Shaming di Dunia Pendidikan}

Fenomena body shaming telah mewabah dan seakan telah dianggap biasa. Hal ini karena pembiaran terhadap fenomena ini masih saja terjadi. Padahal 
dampak yang ditimbulkan justru akan semakin besar jika terus bergulir. Hal ini terbukti dari jumlah korban body shaming yang terus mengalami peningkatan dari tahun ke tahun dan substansi kebenciannya juga beragam. Mabes Polri menyatakan bahwa pada tahun 2018 terdapat 966 kasus body shaming di seluruh Indonesia (Rahmani, 2019).

Di berbagai sekolah yang ada di Amerika Serikat, bullying atau lebih khusus body shaming juga marak terjadi. Fakta yang ditemukan salah satunya anak perempuan lebih kecil kemungkinannya dibandingkan anak laki-laki untuk di-bully secara verbal atau fisik, dan anak-anak obesitas lebih cenderung di-bully secara verbal dan relasional daripada anak-anak non-obesitas. Hal ini membuktikan bahwa tren body shaming merambah kepada dunia anak-anak sekolah yang semestinya tidak bersikap demikian (Morales et al. 2019). Kasus bullying maupun perundungan ke arah fisik (body shaming) menjadi masalah internasional yang berdampak negatif kepada kesejahteraan anak dalam lingkup pergaulannya (Slee and Skrzypiec, 2016).

Penelitian terdahulu terungkap sebuah temuan terhadap seorang mahasiswa Fakultas Hukum dari Universitas Trisakti yang mengalami perlakuan body shaming sejak menempuh Sekolah Dasar menerima cacian karena bentuk tubuhnya yang dianggap besar dan tidak proporsional dan memiliki warna kulit yang gelap. Kemudian hinaan terhadap dirinya ini terus berlanjut hingga Taniya dewasa melalui media sosial maupun dalam kehidupannya sehari-hari. Bahkan Taniya mendapatkan hinaan dari orang yang tidak dikenalnya. Hal yang sering menjadi bahan ejekan adalah tentang warna kulitnya yang gelap hingga ukuran payudara yang dianggap terlalu besar (Michael and Azeharie, 2020).

Fakta di atas tentu begitu mengejutkan, mengingat fenomena demikian seakan dianggap hal yang biasa. Padahal tubuh yang dimiliki seseorang merupakan anugerah yang patut disyukuri, dihargai, dan dihormati. Bukan sebaliknya, fisik yang tidak sesuai dengan kriteria sang penilai yang sejatinya hanya berdasarkan perspektif yang subjektif menjadi bahan hinaan dan ejekan. Tindakan demikian sungguh sangat tidak etis dan tidak adil terkhusus bagi korban body shaming.

Sebuah penelitian menyebut bahwa tindakan body shaming merupakan salah satu bentuk pelecehan psikologis. Ironisnya adalah fenomena pelecehan psikologis masih relatif belum dieksplorasi dibandingkan dengan jenis pelecehan lainnya (misalnya pelecehan seksual). Dalam sebuah penelitian yang menjadikan subjeknya para atlet tergambar bahwa pelecehan psikologis seperti body shaming sangat sering dilakukan melalui tindakan mempermalukan tubuh atlet. Para atlet juga menjelaskan bagaimana mereka menjadi sasaran kekerasan fisik dan pengabaian fisik dari anggota rombongan ketika mereka dianggap kelebihan berat badan atau terlalu gemuk. Pelaku body shaming termasuk pelatih, orang tua, pasangan, dan manajer. Hal ini membuktikan bahwa body shaming telah banyak dilakukan, namun seringkali kurang mendapat perhatian yang serius (McMahon et al., 2021).

Salah satu media yang gencar digunakan untuk melakukan tindakan body shaming adalah media sosial. Sebuah penelitian terdahulu oleh Nur Eva dan Fahyuni menyebutkan bahwa terdapat beberapa faktor yang menjadi penyebab body shaming gempar hadir di media sosial. Faktor tersebut di antaranya karena body shaming dianggap menjadi hal lumrah, bergantung pada pendapat masing-masing orang, dijadikan sebagai bahan kritik membangun, artis sebagai bahan percontohan, terdapat pengaruh budaya, memiliki akun tanpa nama sehingga dapat dengan bebas melontarkan komentar kepada orang lain 
(Rachmah and Baharuddin, 2019; Tambak, 2014).

Temuan lain mengenai body shaming didapati pada media sosial Instagram. Penelitian menyebutkan bahwa sebagian netizen melakukan tindakan body shaming kepada beberapa artis Indonesia di antaranya Yuni Shara dan Audy Item. Body shaming yang diterima lebih terkait dengan tampilan dan bentuk tubuh sang artis (Fitria and Febrianti, 2020). Meski hal ini menjadi hal yang lumrah bagi para selebritis tersebut, namun tetap saja kejadian tersebut membuka lebar perilaku body shaming untuk terus digencarkan.

Sebuah penelitian juga menyebut tentang body shaming yang dilontarkan kepada bintang-bintang film Bollywood. Para bintang kini sering dihujat dan diejek di depan umum atas tindakan atau pun karena penampilan fisik mereka di media sosial. Pergeseran dalam dinamika penggemar bintang ini menjadi semakin bermasalah dalam kasus bintang wanita, yang sering dipermalukan dan diejek di platform media sosial. Bagi penikmat sinema Hindi populer, atau lebih dikenal Bollywood, bintang adalah titik fokus pengalaman sinematik mereka. Hal ini kemudian memicu rasa tidak puas ketika bintangnya memiliki fisik yang tidak sesuai kriteria penontonnya (Mitra, 2020).

Dampak terburuk dari fenomena body shaming adalah ketika sasaran body shaming seringkali ditujukan kepada wanita. Hal ini karena wanita begitu diperhatikan, terutama dalam penampilan fisiknya. Sebuah penelitian menyebut bahwa kekerasan pada gender dianggap sebagai norma bukan sebagai penyimpangan. Maksudnya adalah ketika seseorang mempermalukan tubuh dari seorang wanita atau mungkin bahkan mempermaulukan seksualitasnya bukan dianggap suatu pelanggaran. Tindakantindakan body shame seperti ini sebagai akibat dari pemikiran-pemikiran misoginis yang berkembang, yaitu anggapan bahwa wanita memiliki derajat yang lebih rendah dari lelaki (Murray,
2019). Maka perlu upaya rekonstruksi paradigma baru mengenai hal itu.

Berdasarkan beberapa fakta di atas menggambarkan bahwa body shaming sudah mulai mewabah dan semakin menggambarkan pelanggaran etika yang sangat parah. Hal ini disebabkan oleh maraknya media sosial yang dijadikan sebagai tempat curahan emosi mereka para pembully. Melalui media sosial, para netizen dapat dengan mudah memberikan statement yang menyakitkan kepada mereka yang tidak beruntung secara fisik.

Menyikapi fenomena menyedihkan ini, penting kiranya berbagai upaya harus digaungkan untuk meminimalisir body shaming yang kian meresahkan. Sikap demikan sangat tidak mencerminkan nilai-nilai etika yang semestinya diterapkan. Hubungan pergaulan yang sejatinya dibangun dengan rasa kasih sayang, saling dukung, dan menghargai, tetapi justru dinodai oleh penghinaan terhadap bagian-bagian tubuh yang dinilai tidak sesuai harapan (Michael dan Azeharie, 2020). Terlebih ketika fenomena ini telah merambah ke dunia pendidikan seperti sekolah dan perguruan tinggi, maka tentu akan merusak psikologis yang berdampak kepada kesehatan mental (Adisti, 2020). Oleh sebab itu, peran etika sebagai rambu-rambu pergaulan dan etika pergaulan menjadi sebuah kebutuhan dalam menata kehidupan sosial yang lebih harmoni (Fauzi, 2020).

\section{Menggaungkan Pendidikan Qawlan Ma'rufa Guna Menyikapi Body Shaming}

Persoalan etika pergaulan yang banyak diabaikan menjadi problem yang tak baru lagi. Pasalnya hal ini terus menerus dilakukan dan menjadi sebuah kebiasaan yang begitu buruk. Dalam dunia pertemanan misalnya, seringkali terdapat perkataan yang tidak terkontrol seperti penghinaan terhadap bagian tubuh seseorang "gendut, kurus, dan lain-lain". Sehingga terkadang tindakan demikian membuat hubungan pertemanan menjadi retak dan bahkan masalah-masalah yang 
dianggap sepele seperti itu akan berujung kepada perkelahian. Maka sepantasnya budaya ini harus dirubah dengan mengimplementasikan etika pergaulan yang terbaik menurut tuntunan dalam Islam.

Qawlan ma'rufa merupakan salah satu tuntunan al-Qur'an untuk senantiasa memberikan perkataan yang terbaik dan layak untuk diucapkan kepada orang lain. Perkataan terbaik ini tentu saja perkataan yang memiliki nilai-nilai etika dan menenangkan bagi siapa pun yang mendengarkannya. Sebab qawlan ma'rufa merupakan pembicaraan yang bermanfaat, memberi tambahan pengetahuan, mencerahkan pemikiran, dan memberi pemecahan masalah (Aziz, 2019). Qawlan ma'rufa disebutkan pada beberapa ayat seperti pada QS. An-Nisa ayat 5 dan 8, QS. Al-Baqarah ayat 263, dan QS. Al-Ahzab ayat 32. Di antaranya, Allah SWT berfirman dalam Surat An-Nisa ayat 5 sebagai berikut.

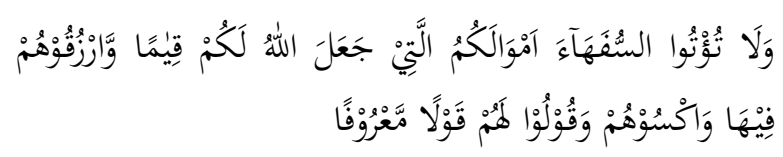

Artinya: "Dan janganlah kamu serahkan kepada orang yang belum sempurna akalnya, harta (mereka yang ada dalam kekuasaan) kamu yang dijadikan Allah sebagai pokok kehidupan. Berilah mereka belanja dan pakaian (dari hasil harta itu) dan ucapkanlah kepada mereka perkataan yang baik." (Kementerian Agama, 2004).

Kandungan ayat ini adalah tentang perintah berbuat baik kepada keluarga dan orang-orang yang yang menjadi tanggungan dengan memberikan infaq dalam bentuk rizki dan pakaian, serta menuturkan perkataan dan mewujudkan akhlak yang baik. Melalui ayat ini, ditekankan mengenai perkataan yang baik sebagai implementasi dari peruatan ihsan kepada orang lain. Sebab sejatinya perkataan yang terbaik akan mudah meresap ke dalam hati dan menenangkan bagi pendengarnya (Abdullah, 2004).
Meskipun konteks perkataan yang baik dalam ayat ini ditujukan kepada anak-anak yatim, namun sejatinya juga berlaku umum ketika diberikan kepada sesama. Kata-kata yang baik yang dimaksud adalah kata-kata yang diucapkan secara terus terang mengenai harta anak yatim yang menjadi hak mereka. Hal ini tentu sebagai sebuah manifestasi bahwa anak yatim harus diberikan kasih sayang, bukan sebaliknya dibenci bahkan dianiaya (Hamka, 2015; Hamzah, Tambak, and Ariyani, 2017).

Jika ditelaah lebih dalam, al-Qur'an Surat An-Nisa ayat 5 ini menjelaskan tentang ketidakmampuan seorang anak dalam mengelola harta peningalan ahli warisnya. Jika harta tersebut diambil, maka diperkirakan harta itu akan habis tak berarti. Oleh sebab itu, untuk sementara harta itu dititipkan kepada para wali mereka. Maka tugas para wali adalah menjaga harta itu dan menjaga sikap kepada anak-anak yatim tersebut dengan menuturkan perkataan yang baik dan berbuat ihsan (Khatibah, 2016).

Kontekstualisasi ayat ini menitikberatkan kepada implementasi qawlan ma'rufa yang semestinya dilakukan terutama kepada sasaran yang memang sangat memerlukan dan menjadi sebuah keharusan. Namun terlepas dari hal tersebut, terkait fenomena body shaming sejatinya qawlan ma'rufa menjadi sebuah keharusan yang diterapkan dalam pergaulan agar tidak mudah menjustifikasi, menghina, dan memandang rendah fisik orang lain.

Selain al-Qur'an Surat An-Nisa ayat 5 di atas, frase qawlan ma'rufa juga disebutkan dalam ayat yang lain yaitu Surat An-Nisa ayat 8 sebagai berikut.

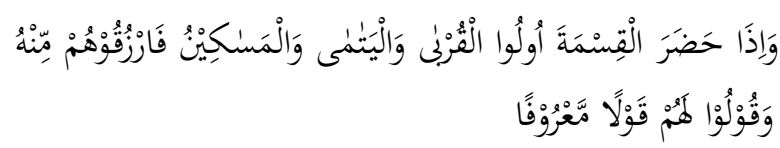

Artinya: "Dan apabila sewaktu pembagian itu hadir beberapa kerabat, anak-anak yatim dan orang-orang miskin, maka berilah mereka dari harta itu (sekedarnya) 
dan ucapkanlah kepada mereka perkataan yang baik." (Kementerian Agama, 2004).

Ayat tersebut menjelaskan tentang pentingnya penggunaan qawlan ma'rufa yaitu perkataan yang baik dan sesuai dengan kebiasaan sehingga perkataanperkataan yang dilontarkan tidak bertentangan dengan nilai-nilai yang berlaku umum. An-Nisa ayat 8 menganjurkan agar pesan disampaikan menggunakan redaksi yang sesuai dengan kebiasaan baik yang berlaku dalam masyarakat (Shihab, 2012). Hal ini memberi arahan bahwa perkataan yang semestinya dilontarkan kepada sesama dalam dunia pergaulan adalah perkataan yang wajar dan sesuai dengan kadar kebiasaan. Dengan demikian, sebuah perkataan dapat dikatakan ma'ruf adalah ketika perkataan tersebut tidak kotor, tidak dusta, dan tidak menyakiti orang lain.

Qawlan ma'rufa juga menjadi salah satu prinsip komunikasi Islam yang berarti perkataan baik, santun, ungkapan yang pantas, tidak kasar, dan menggunakan sindirian (tidak menyinggung perasaan), dan tidak menyakitkan. Qawlan ma'rufa juga menjadi sebuah perkataan yang memberi manfaat dan menghasilkan kebaikan (maslahat) (Muslimah, 2016). Qawlan ma'rufa merupakan melembutkan katakata dan menepati janji. Kontekstualisasi ayat di atas memerintahkan tentang pemberian harta kepada anak yatim yang diiringi oleh perkataan baik serta tidak menyakiti perasaan mereka (Ismaya et al. 2019).

Selain itu, dalam sebuah penelitian menyebut bahwa salah satu ikhtiar membentuk karakter anak adalah melalui pembiasaan komunikasi yang baik. Qawlan ma'rufa menjadi salah satu pengajaran komunikasi yang baik untuk anak sejak dini. Prinsip komunikasi ini diajarkan agar dapat mengimplementasikan perkataan yang halus, menyenangkan, serta tidak membuat malu dan menyakiti orang yang mendengarnya (Husen, 2017; Tambak, et al. 2018). Pembiasaan ini tentunya dilakukan dalam lingkup keluarga sebagai madrasatul ula untuk sang anak.

Anjuran mengatakan yang baik kepada orang lain dengan kata lain tidak menghina fisiknya juga didukung oleh larangan Allah dalam Alquran sebagaimana terdapat dalam QS. AlHujurat ayat 11 sebagai berikut.

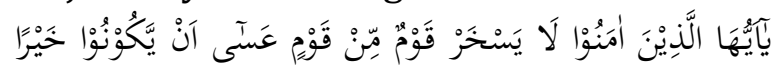

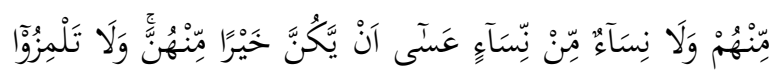

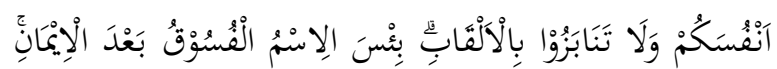

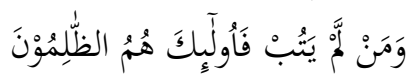

Artinya: "Wahai orang-orang yang beriman! Janganlah suatu kaum mengolokolok kaum yang lain (karena) boleh jadi mereka (yang diperolok-olokkan) lebih baik dari mereka (yang mengolok-olok) dan jangan pula perempuan-perempuan (mengolok-olokkan) perempuan lain (karena) boleh jadi perempuan (yang diperolok-olokkan) lebih baik dari perempuan (yang mengolok-olok). Janganlah kamu saling mencela satu sama lain dan janganlah saling memanggil dengan gelar-gelar yang buruk. Seburukburuk panggilan adalah (panggilan) yang buruk (fasik) setelah beriman. Dan barangsiapa tidak bertobat, maka mereka itulah orang-orang yang zalim." (Kementerian Agama, 2004).

Ayat tersebut berkenaan dengan Bani Salamah. Nabi Muhammad SAW tiba di Madinah pada saat orang-orang biasanya mempunyai dua atau tiga nama. Pada suatu saat Rasulullah memanggil seseorang dengan salah satu namanya, tetapi ada orang yang berkata: "Ya Rasulallah! Sesungguhnya ia marah dengan panggilan itu." Kemudian ayat la tanabazu bil alqab (janganlah kamu panggil memanggil dengan gelar yang buruk turun sebagai larangan untuk memanggil orang dengan sebutan yang buruk atau tidak disukainya (Sholeh, 2011; Hamzah, et al. 2020). 
Syaikh Imam al-Qurthubi dalam tafsirnya menjelaskan bahwa terdapat tiga hal penting terkait ayat tersebut. Pertama, larangan untuk mengolok-olok karena sesungguhnya yang memperolok belum tentu lebih baik dari yang diperolok. Kedua, Allah menyebutkan kaum wanita dalam ayat tersebut karena kecenderungan yang sering memperolok adalah wanita. Ketiga, larangan untuk memberikan gelar-gelar yang buruk dan bermaksud menjelekkan (Al-Qurthubi, 2008).

Berdasarkan kandungan ayat tersebut terlihat bahwa body shaming juga menjadi bagian dari sikap mengolok-olok dan memberi gelar-gelar yang tidak pantas kepada orang lain. Berlandaskan kepada ayat tersebut tentu sikap demikian adalah terlarang. Sebab akan menimbulkan rasa sakit hati bagi mereka yang dihina, padahal sejatinya kemuliaan atau keistimewaan bukan dinilai berdasarkan fisiknya dan orang yang menghina tidaklah pasti lebih mulia dari mereka yang dihina.

Sepatutnya kontekstualisasi dari ayat ini berusaha untuk mengajak setiap orang agar mempertimbangkan ucapanucapan yang keluar dari mulut masingmasing dalam pergaulan. Terlebih ketika ramainya body shaming yang tidak asing di kalangan generasi muda seperti pelajar dan mahasiswa. Maka pendidikan komunikasi yang baik perlu digaungkan, bukan hanya perilaku saja yang diperhatikan namun ucapan juga amat penting dan urgen. Sebab terkadang ucapan dapat menjadi bumerang bagi penuturnya ketika hal itu merugikan orang lain (Sukandar and Hori, 2020; Sholeh, 2011).

Maka dalam menggaungkan pendidikan qawlan ma'rufa sebagai etika pergaulan dalam menyikapi fenomena body shaming yang marak terjadi setidaknya dapat dilakukan pada ranahranah penting berikut:

\section{Pertama, Melalui Pendidikan Keluarga}

Misi pertama yang harus dijalankan sebagai langkah awal pembiasaan qawlan ma'rufa adalah melalui pendidikan akhlak dalam keluarga. Tanggung jawab terpenting dalam keluarga adalah mengajarkan pendidikan akhlak. Pendidikan akhlak atau moral berkutat pada hal-hal yang berkenaan dengan prinsip moral dan keutamaan sikap serta watak (tabiat) yang harus dimiliki oleh anak sejak masa pemula hingga ia menjadi seorang mukallaf (Afriantoni, 2015). Misi ini sejatinya terus dipegang oleh setiap orang tua guna mengembangkan pribadipribadi berkualitas dalam masyarakat.

Membiasakan anak untuk selalu mengatakan hal-hal yang baik dilakukan sejak ia kecil. Hal ini merupakan tugas orang tua untuk memberikan keteladanan. Sebab di antara metode pendidikan akhlak yang dicontohkan oleh Rasulullah adalah dengan keteladanan dan praktik langsung. Keteladanan ini dilakukan melalui interaksi langsung terhadap anak dengan bercanda, tidak marah-marah, dan tidak mencela mereka sedikitpun. Maka hal ini menanamkan suatu contoh kepada anak untuk selalu berkata yang baik dan lembut serta menghindari perkataan yang kotor atau kasar (Kartikowati, 2020).

Menurut sebuah penelitian, dalam teori Linda Zagzebski's exemplarist moral theory (EMT) disebutkan bahwa contoh dapat berfungsi sebagai panduan untuk pelatihan moral dan mendukung 'pembelajaran kebajikan dengan meniru. Hal ini menunjukkan bahwa teladan atau contoh-contoh kebajikan dan pendidikan, berkontribusi pada kasus penyimpanganpenyimpangan moral dan menjadikan sebuah basis teladan bagi pendidikan karakter (Watson, 2019).

Selain teladan dari orang tua, anak dibiasakan untuk bergaul bersama temantemannya dengan tingkah yang sopan dan bersahabat. Begitu pun dalam memilihkan teman bergaul, orang tua harus cermat dalam mengawasi anak agar tak salah berteman dan terpengaruh kepada hal-hal 
yang tidak baik. Sebuah studi menyebut bahwa untuk membiasakan anak memiliki attitude yang baik terutama kepada orang lain maka upaya orang tua adalah dengan membangun etika sosial yang baik sejak dini. Di antara langkah membangun etika sosial tersebut antara lain dengan mengajarkan budi pekerti, menanamkan moralitas, dan membentuk kepribadiannya yang kuat (Asdiqoh, 2017; Tambak, et al. 2020).

Tidak dapat dipungkiri bahwa untuk membentuk suatu kebiasaan yang baik diperlukan sebuah teladan. Penelitian Haibah et al. (2020) menjelaskan bahwa untuk dapat membiasakan karakter yang baik pada diri anak atau peserta didik diperlukan pembiasaan dan keteladanan. Hal-hal yang dibiasakan misalnya bersikap jujur, sopan santun, dan berbagai akhlak mulia lainnya.

\section{Kedua, Melalui Pendidikan di Sekolah}

Lembaga pendidikan menjadi wadah penting dalam pembentukan karakter anak. Sebab setelah lingkungan keluarga yang mengajarkan nilai-nilai etika dasar kepada anak, maka lembaga pendidikan seperti sekolah selanjutnya mengembangkan dan menguatkan pendidikan tersebut. Sebuah studi terdahulu menjelaskan bahwa lembaga pendidikan seperti sekolah bertanggung jawab mengembangkan kecerdasan emosional anak selain kecerdasaran intelektual. Hal ini karena pada zaman sekarang, keluarga memiliki kesempatan yang terbatas untuk memberikan pendidikan moral kepada anggotanya. Oleh karenanya sekolah turut berperan aktif guna menciptakan peserta didik yang berkualitas baik intelektual maupun emosionalnya (Saleh, 2016; Tambak, Syahraini, and Desi Sukenti., 2020).

Ada banyak hal yang dapat diberikan oleh lembaga pendidikan guna membentuk karakter peserta didik terutama dalam membiasakan qawlan ma'rufa sebagai etika pergaulan. Pertama, sekolah senantiasa menciptakan budaya santun yang harus ditanamkan pada setiap peserta didiknya. Hal ini dapat dilakukan dengan membuat peraturanperaturan untuk mewujudkan pembiasanpembiasaan tersebut. Berdasarkan penelitian terdahulu terbukti bahwa aturan ataupun tata tertib sekolah dapat menanamkan pembiasaan yang baik, misalnya bertutur sapa secara sopan, tidak acuh terhadap peringatan guru, dan berbagai kebiasaan baik lainnya. Hal ini karena aturan yang pada awalnya bersifat memaksa, namun jika terus dilakukan akan menjadi sebuah kebiasaan dan tidak lagi menjadi beban bagi peserta didik (Suradi, 2017; Noer, Tambak, and Rahman, 2017). Penelitian yang lain oleh Rangkuti and Siregar (2020) bahwa peraturan menjadi cara ampuh untuk membentuk karakter peserta didik dengan memberi tanggung jawab melalui peraturan-peraturan yang ada baik secara langsung atau tidak langsung. Namun yang terutama adalah pemberian kebiasaan dan keteladanan disamping diperkuat dengan peraturan.

Kedua, melalui lembaga pendidikan seperti sekolah dapat mendeklarasikan pergaulan yang dilandasi nilai-nilai kebersamaan dan harmoni terutama dalam lingkungan sekolah. Tindakan yang dilakukan misalnya dengan membentuk komunitas-komunitas peserta didik yang mensosialisasikan pentingnya etika pergaulan yang baik seperti membudayakan berkata sopan dan tidak menghina sesama teman. Langkahlangkah sederhana ini setidaknya dapat meminimalisir perilaku body shaming yang kian marak terjadi terutama di lingkungan sekolah (Munifah and Dodi, 2020; Ahmad, and Tambak, 2018). Bahkan akhir-akhir ini di sekolah maupun madrasah dituntut untuk menciptakan iklim pergaulan yang harmonis ditengah berbagai keberagaman yang ada dengan memperluas cara pandang peserta didik dalam melihat realitas di sekitarnya (Hamdi and Musthofa, 2020). 
Senada dengan hal di atas, menurut sebuah penelitian tentang pendidikan karakter yang ditawarkan di Inggris bahwa ada salah satu tawaran untuk mensuksesakan pendidikan karakter yaitu prioritas sebuah pengakuan berdasarkan honneth's theory of recognition. Pengakuan yang dimaksud berasal dari lingkungan di sekeliling individu yang berupaya mendukung suatu etika moral yang semestinya dijalankan. Pengakuan orang lain sebagai prasyarat untuk tindakan moral memberikan dasar untuk pendekatan pendidikan karakter yang memperhitungkan hubungan intersubjektif di sekolah dan konteks sosial yang lebih luas di mana karakter dibentuk (Bates, 2019; Tambak, Ahmad, and Sukenti, 2020). Hal ini menunjukkan bahwa pengenalan qawlan ma'rufa di sekolah menjadi sebuah prioritas yang harus mendapat pengakuan dari masyarakat sekolah itu sendiri maupun masyarakat luas secara umum.

Statement di atas juga didukung oleh sebuah penelitian yang menjelaskan bahwa pendidikan karakter perlu mencakup mempersiapkan peserta didik untuk, dan melibatkan mereka dalam pergaulan, termasuk yang terkait dengan kewarganegaraan. Keterlibatan seperti itu membutuhkan kebajikan, seperti kejujuran, kasih sayang, keterbukaan pikiran, dan lain-lain. Hal ini menunjukkan bahwa membaurkan peserta didik pada masyarakat sekolah yang mendukung terciptanya good character seperti "pembiasaan berkata baik" dan "budaya santun" sebagai bagian dari upaya pembentukan karakter yang lebih luas (Peterson, 2020).

Jika dikaitkan dengan pendidikan Islam, pembiasaan-pembiasaan ibadah juga menjadi faktor pembentuk akhlak yang sangat ampuh. Penelitian terdahulu oleh Tambak et al. (2020) bahwa untuk internalisasi nilai-nilai Islam dalam mengembangkan akhlak aktual siswa diwujudkan melalui pengamalan Salat Sunnah Dhuha, Salah Fardu berjamaah, tahfiz Qur'an dan berbagai aktivitas lain yang mendukung. Hal ini menunjukkan bahwa akhlak baik seperti "menghindari body shaming" juga dapat diwujudkan melalui pembiasaan berupa ibadah-ibadah sederhana yang dapat dilakukan di sekolah atau madrasah.

Sejatinya, sekolah diibaratkan sebagai sebuah negara, peserta didik menjadi warga dari sekolah. Mereka dituntut bekerja sama atau pada saat-saat tertentu melakukan musyawarah. Peran penting sosialisasi qawlan ma'rufa amat tepat diimplementasikan sebagai pendidikan karakter yang terbentuk dari pembauran tersebut. Maka melalui komunitas-komunitas khusus mereka berupaya mensosialisasikan pesan-pesan harmoni kepada warga sekolah yang lain. Hal ini dilakukan agar penerapan pendidikan karakter tidak hanya berfokus kepada individu, melainkan juga melalui pergaulan yang mencakup lingkup lebih luas dan beragam (Ahmad, Tambak, and Hasanah, 2018).

Selain itu, untuk mewujudkan pembiasaan karakter yang baik berupa qawlan ma'rufa di sekolah juga didukung oleh pendidikan agama yang baik. Sebuah penelitian mengenai perspektif guru agama tentang kontribusi religious education terhadap pendidikan karakter di sekolah bahwa pendidikan agama memiliki andil dalam pembentukan karakter. Meskipun pada beberapa sekolah yang berbasis non-agamis terdapat perbedaan pendapat mengenai hal itu (Metcalfe and Moulin-Stożek, 2020). Namun tidak dapat dipungkiri bahwa pendidikan agama mengajarkan kebaikan-kebaikan yang langsung menyentuh kepada bimbingan karakter atau akhlak yang lebih spesifik dalam Islam.

Demikian bahwa qawlan ma'rufa menjadi solusi dalam menyikapi fenomena body shaming. Namun implikasi dari konsep ini bukanlah perkara mudah, melainkan perlu usaha yang keras dalam menerapkannya sebagai etika pergaulan 
terutama di kalangan anak muda. Beberapa langkah yang dapat diberikan terutama untuk tindakan pencegahan melalui keluarga dan lingkungan pendidikan. Pertama, orang tua dalam keluarga memiliki peran penting untuk membentuk karakter anak melalui keteladanan dan pengawasan yang baik. Kedua, melalui lembaga pendidikan budaya santun dibiasakan dengan merevitalisasi peraturan sekolah yang terkait hal tersebut serta melalui komunitas-komunitas peserta didik yang membangun nilai-nilai pergaulan sehat. Maka misi penting ini setidaknya dapat mencegah perilaku body shaming (Sakinah, 2018).

Berdasarkan beberapa paparan di atas terlihat bahwa qawlan ma'rufa sejatinya dapat menjadi solusi dalam mengatasi maupun mencegah terjadinya fenomena body shaming dalam dunia pergaulan. Hal ini dapat dilakukan melalui pembiasaan baik dalam lingkungan keluarga maupun pendidikan. Sebab sejatinya, tanpa ada pembiasaan, maka akan sulit menerapkan dan menghilangkan budaya yang sudah terlanjur menjamur. Oleh karenanya peran berbagai pihak amat penting dalam mensukseskan misi mulia ini.

Menghadirkan qawlan ma'rufa dalam pergaulan semestinya selalu diupayakan, mengingat fenomena body shaming yang kian merajalela. Dampak terburuknya adalah ketika body shaming menimpa seseorang akan memunculkan trauma psikologi yang berkepanjangan. Berawal dari hal tersebut kadang dapat menghilangkan rasa percaya diri, takut bergaul, dan bahkan mengalami gangguan kejiwaan. Akibat-akibat buruk inilah yang ditakutkan. Sehingga memandang urgen penerapan pendidikan akhlak pada setiap generasi terkhusus peserta didik di sekolah dengan dukungan dari para ustadz-ustadzah dan para orang tua di rumah. Jika keduanya saling bersinergi dan bekerja sama, maka perlahan body shaming akan jauh dari dunia pergaulan saat ini.

\section{PENUTUP}

Fenomena body shaming yang marak terjadi terkhusus di dunia pendidikan begitu mengkhawatirkan. Ada banyak temuan yang menjelaskan tentang berbagai hinaan yang diberikan misalnya kulit yang gelap atau tubuh yang terlalu gemuk serta berbagai hinaan yang lain. Bahkan pada kasus tertentu, perlakuan body shaming diterima semenjak Sekolah Dasar hingga Dewasa. Fakta ini begitu mencengangkan dan penanganan body shaming masih minim mendapat perhatian. Sebab tindakan body shaming dilihat dari berbagai persepsi yang berbeda-beda pada masing-masing orang dalam menilainya. Sehingga, body shaming dianggap menjadi hal yang biasa-biasa saja. Akibat yang paling ditakutkan adalah ketika budaya pergaulan di sekolah/madrasah terkontaminasi dengan body shaming. Oleh karenanya etika pergaulan amat penting hadir dalam menyikapi fenomena ini. Salah satunya adalah dengan menghadirkan pendidikan qawlan ma'rufa sebagai bagian dari etika pergaulan untuk menyikapi fenomena body shaming. Pendidikan Qawlan ma'rufa dimaknai sebagai suatu pendidikan yang khusus menata komunikasi dalam pergaulan peserta didik dengan menggunakan perkataan yang baik, pantas, dan sesuai dengan kebiasaan untuk diucapkan. Esensi dari qawlan ma'rufa juga ternyata menjadi perkataan yang dapat bersifat abstrak dan memperhalus redaksi sehingga dapat diterima dengan baik oleh pendengarnya. Maka sepatutnya perkataan inilah yang senantiasa diberikan dalam dunia pergaulan baik kepada teman maupun orang lain. Implementasi dari misi penting ini dapat dilakukan melalui pendidikan keluarga dengan adanya pembiasaan dan teladan dari orang tua. Selain itu juga dari pendidikan di sekolah dengan merevitalisasi pendidikan akhlak serta 
budaya santun melalui peraturan dan iklim pergaulan di sekolah/madrasah. Pada akhirnya, pendidikan dan pembiasaan inilah yang menjadi senjata ampuh dalam merekonstruksi kembali budaya-budaya yang menggambarkan nilai-nilai Islam. Implikasi penelitian ini setidaknya memberikan konstribusi terhadap khazanah pesan-pesan al-Qur'an terutama dalam pendidikan komunikasi untuk generasi sekarang. Hal ini sebagai upaya preventif dalam mencegah menjamurnya tren body shaming yang diupayakan melalui pembiasaan akhlak dan budaya santun. Namun penelitian ini hanya bersifat konsep solutif yang ditawarkan, sehingga perlu ada upaya pembuktikan berupa eksperimen atau penerapan dari solusi-solusi di atas yang tepat dilakukan dalam penelitianpenelitian berikutnya.

\section{DAFTAR RUJUKAN}

Abdullah. Lubabut Tafsir Min Ibnil Katsir. Translated by M. Abdul Ghoffar and Abu Ihsan al-Atsari. Bogor: Pustaka Imam Syafi'i, 2004.

Adisti, Prisna. Personality Plus for Teens. Yogyakarta: Pustaka Grhatama, 2010.

Afriantoni. Prinsip-Prinsip Pendidikan Akhlak Generasi Muda: Percikan Pemikiran Ulama Sufi Turki Beiduzzaman Said Nursi. Yogyakarta: Deepublish, 2015.

Ahmad, Muhammad Yusuf, Syahraini Tambak, and Uswatun Hasanah. "Pengaruh Kecerdasan Emosional terhadap Penyesuaian Diri Mahasiswa Thailand." Al-Hikmah: Jurnal Agama dan Ilmu Pengetahuan 15.2 (2018): 16-30. https://doi.org/10.25299/alhikmah:jaip.2018.vol15(2).2374.

Ahmad, Muhammad Yusuf, and Syahraini Tambak. "Penanaman Nilai-Nilai Pendidikan Akidah Melalui Mata Pelajaran Sejarah Kebudayaan Islam (SKI)." Al-Hikmah: Jurnal Agama dan Ilmu Pengetahuan 15.1 (2018): 24-
41.

https://doi.org/10.25299/jaip.2018. vol15(1).1581.

Ahmad, Muhammad Yusuf, Syahraini Tambak, and Mira Syafitri. "Etika Pergaulan Islami Santri Madrasah Aliyah (MA) di Pesantren Jabal Nur Kecamatan Kandis Kabupaten Siak." Al-Hikmah: Jurnal Agama dan Ilmu Pengetahuan 13.2 (2016): 206-226. https://doi.org/10.25299/al-

hikmah:jaip.2016.vol13(2).1524.

Ahmad, Mawardi. "Hubungan Potensi Akal dengan Kreativitas Belajar Siswa Bidang Studi Pendidikan Agama Islam di SMK Kanada Sakura Indonesia (KANSAI) Pekanbaru." Jurnal Pendidikan Agama Islam AlThariqah 2.1 (2017): 51-72. https://doi.org/10.25299/althariqa h.2017.vol2(1).647.

Ahmad, Mawardi, and Syahraini Tambak. "Penerapan Metode Diskusi Dalam Meningkatkan Hasil Belajar Murid Pada Pelajaran Fiqh." Al-Hikmah: Jurnal Agama Dan Ilmu Pengetahuan 15.1 (2018): 64-84. https://doi.org/10.25299/jaip.2018. vol15(1).1585.

Al-Qurthubi, Syaikh Imam. Tafsir AlQurthubi. Translated by Asmuni, Jakarta: Pustaka Azzam, 2008.

Al-Munawar, Said Agil Husain, Syahraini Tambak, and Umi Kalsum. Aktualisasi nilai-nilai Qu'rani dalam sistem pendidikan Islam. Ciputat Press, 2003.

Arifin, Yanuar. Pemikiran-Pemikiran Emas Para Tokoh Pendidikan Islam. Yogyakarta: IRCiSoD, 2017.

Asdiqoh, Siti. "Peran Orang Tua dalam Pemahaman Etika Sosial Anak." ThufuLA: Jurnal Inovasi Pendidikan Guru Raudhatul Athfal 5.2 (2018): 308-331. doi:10.21043/thufula.v5i2.3477.

Aziz, Moh. Ali. Public Speaking: Gaya Dan Teknik Pidato Dakwah. Jakarta: Prenadamedia Group, 2019. 
Baiquni, M., and Puji Astuti. Merajut Pengalaman: Pendidikan Untuk Pembangunan Berkelanjutan UGM. Yogyakarta: Gajah Mada University Press, 2018.

Bates, Agnieszka. "Character Education and the 'Priority of Recognition."' Cambridge Journal of Education 49.6 (2019): 695-710. doi:10.1080/0305764X.2019.15905 29.

Bombak, Andrea E., et al. "Fat Acceptance 101: Midwestern American Women's Perspective on Cultural Body Acceptance." Health Sociology Review, 28.2 (2019): 194-208. doi:10.1080/14461242.2019.16041 50.

Dolezal, Luna. The Body and Shame: Phenomenology, Feminism, and The Socially Shaped Body. London: Lexington Books, 2015.

Fauzi, Ichwan. Etika Muslim. Wisdom Jakarta: Science Sea, 2020.

Fauzia, Tri Fajariani, and Lintang Ratri Rahmiaji. "Memahami Pengalaman Body Shaming Pada Remaja Perempuan." Jurnal Interaksi (Online) 7.3 (2019): 38-48.

Fitria, Kusnul, and Yessi Febrianti. "Pemaknaan dan Sikap Perilaku Body Shaming di Media Sosial." Diakom: Jurnal Media dan Komunikasi 3.1 (2020): 12-25. doi:10.17933/diakom.v3i1.78.

Haibah, Mujahidatul, et al. "Pembiasaan Membentuk Karaktek Peserta Didik Madrasah Miftahul Huda Musi Rawas Utara." Jurnal Pendidikan Agama Islam Al - Thariqah 5.2 (2020): 24-32. DOI: https://doi.org/10.25299/althariqah.2020.vol5(2).5341

Hamdi, Saibatul, and Khabib Musthofa. "The Concept of Lita'arofu as a Multicultural Education Model to Response Religious Hate Speech." AtTarbiyah: Journal of Islamic Culture and Education 15.2 (2020): 91-104. doi:10.18326/attarbiyah.v5i2.91104.

Hamka. Tafsir Al-Azhar. Jakarta: Gema Insani, 2015.

Hamzah, Desi Sukenti, Syahraini Tambak, and Wisudatul Ummi Tanjung. "Overcoming self-confidence of Islamic religious education students: The influence of personal learning model." Journal of Education and Learning (EduLearn) 14.4 (2020): 582-589.

https://doi.org/10.11591/edulearn. v14i4.16759.

Hamzah, Hamzah, Syahraini Tambak, and Nella Ariyani. "Upaya Guru Pendidikan Agama Islam dalam Pembentukan Kepribadian Islam Siswa di SMA Negeri 2 Kelayang Kabupaten Indragiri Hulu." AlHikmah: Jurnal Agama dan Ilmu Pengetahuan 14.1 (2017): 76-95. https://doi.org/10.25299/alhikmah:jaip.2017.vol14(1).1528.

Hardiono. "Sumber Etika dalam Islam." Jurnal Al-Aqidah: Jurnal Ilmu Aqidah Filsafat 12.2 (2020): 26-36. DOI:https://www.ejournal.uinib.ac.i d/jurnal/index.php/alaqidah/article /download/2270/1595.

Hestianingsih. "Stop Body Shaming Sesama Wanita Di Media Sosial Kamu Bisa Dipenjara." Wolipopstyle, 22 Nov. 2018, https://wolipop.detik.com/healthand-diet/d-4312143/stop-bodyshaming-sesama-wanita-di-mediasosial-kamu-bisa-dipenjara.

Hidayat, Rahmad, et al. "Hubungan Perlakuan Body Shaming dengan Citra Diri Mahasiswa." Jurnal Keperawatan Jiwa 7.1 (2019): 79-86. doi:10.26714/jkj.7.1.2019.79-86.

Husen, Herlina. 'Metode Ta'dib dan Komunikasi Islami Menurut Perspektif Al-Qur'an dan Hadist dalam Pembangunan Karakter Anak Usia Dini." GOLDEN AGE: JURNAL PENDIDIKAN ANAK USIA DINI 1.2 
(2017):

43-50.

doi:10.29313/ga.v1i2.3385.

Idi, Abdullah. Dinamika Sosiologis Indonesia: Agama dan Pendidikan dalam Perubahan Sosial. Yogyakarta: LKiS, 2015.

Izzan, Ahmad. Metodologi Ilmu Tafsir. Bandung: Tafakur, 2011.

Ismaya, Ismaya, et al. "Metode Pelayanan Informasi Pensertipikatan Tanah Negara Melalui Program Pendaftaran Tanah Sistematis Lengkap Di Kantor Pertanahan Kabupaten Enrekang." Jurnal Diskursus Islam 7.1 (2019): 34-52. doi:https://doi.org/10.24252/jdi.v7i 1.9708.

Janna, Nilda M., and Aryantialfi. "Etika Dalam Perspektif Filsafat Islam." OSF Preprints, 22 Jan. 2021. Web. DOI:10.31219/osf.io/umeyx.

Kamil, Sukron. Etika Islam: Kajian Etika Sosial Dan Lingkungan Hidup. Jakarta: Kencana, 2021.

Kartikowati, Endang, and Zubaedi. Pola Pembelajaran 9 Pilar Karakter Pada Anak Usia Dini Dan DimensiDimensinya. Jakarta: Prenadamedia Group, 2020.

Kementerian Agama. Al-Qur'an dan Terjemahannya. Jakarta: CV Penerbit J-ART, 2004.

Khatibah. "Prinsip-Prinsip Komunikasi Pustakawan (Perspektif Komunikasi Islam)." Jurnal Iqra' 10.2 (2016): 4753. doi: https://www.neliti.com/publication s/196943/prinsip-prinsip-

komunikasi-pustakawan-persfektifkomunikasi-islam

Mardawani. Praktis Penelitian Kualitatif Teori Dasar dan Analisis Data dalam Perspektif Kualitatif. Yogyakarta: Deepublish, 2020.

McMahon, Jenny, et al. "Body Shaming and Associated Practices as Abuse: Athlete Entourage as Perpetrators of Abuse." Sport, Education and Society (2021):

1-14. doi:10.1080/13573322.2021.18905 71.

Metcalfe, Jason, and Daniel Moulin-Stożek. “Religious Education Teachers' Perspectives on Character Education." British Journal of Religious Education (2020): 1-12. doi:10.1080/01416200.2020.17130 49.

Micheal, and Suzy S. Azeharie. "Perlawanan Penyintas Body Shaming Melalui Media Sosial." Koneksi 4.1 (2020): 138-46. doi:10.24912/kn.v4i1.6642.

Mitra, Sreya. "Trolled, Body-Shamed and Slut-Shamed: The Desecration of the Contemporary Bollywood Female Star on Social Media." Celebrity Studies $11.1 \quad$ (2020): 101115.doi:10.1080/19392397.2020.17 04388.

Morales, Danielle X., et al. "School Bullying, Body Size, and Gender: An Intersectionality Approach to Understanding US Children's Bullying Victimization." British Journal of Sociology of Education 40.8 (2019): 1121-1137. doi:10.1080/01425692.2019.16461 15.

Muhajir. "Body Shaming, Citra Tubuh, dan Perilaku Konsumtif (Kajian Budaya Populer)." Jurnal Agama dan Kebudayaan 5.1 (2019): 77-90.

Munifah, and Limas Dodi. Rekonsepsi Pendidikan Karakter Era Kontemporer. Bandung: CV Cendekia Press, 2020.

Murray, Jessica. "Violence and the Gendered Shaming of Female Bodies and Women's Sexuality: A Feminist Literary Analysis of Selected Fiction by South African Women Writers." Current Writing: Text and Reception in Southern Africa 31.1 (2019): 2-10. doi:10.1080/1013929X.2018.15470 13

Muslimah. "Etika Komunikasi dalam Perspektif Islam." Jurnal Sosial Budaya 13.2 (2016): 115-125. DOI: 
http://dx.doi.org/10.24014/sb.v13i 2.3534 .

Noer, Ali, Syahraini Tambak, and Harun Rahman. "Upaya Ekstrakurikuler Kerohanian Islam (ROHIS) dalam Meningkatkan Sikap Keberagamaan Siswa di SMK Ibnu Taimiyah Pekanbaru." Jurnal Pendidikan Agama Islam Al-Thariqah 2.1 (2017): 21-38.

https://doi.org/10.25299/althariqa h.2017.vol2(1).645.

Nasution, Nani Barorah, and Ernita Simanjuntak. "Pengaruh Body Shaming terhadap Self-Esteem Siswa SMP." Jurnal Pendidikan: Teori, Penelitian, dan Pengembangan 5.7 (2020): 962-68.

Nurrahmi, Febri, et al. Etika dan Bisnis dalam Jurnalisme. Aceh: Syiah Kuala University Press, 2021.

Peterson, Andrew. "Character Education, the Individual and the Political." Journal of Moral Education 49.2 (2020): 143-157. doi:DOI: http://dx.doi.org/10.17977/jptpp.v 5i7.13770.

Rachmah, Nur Eva, and Fahyuni Baharuddin. "Faktor Pembentuk Perilaku Body Shaming Di Media Sosial." Prosiding Seminar Nasional Dan Call Paper Psikologi Sosial 2019 (Universitas Surabaya) (2019): 6673.

Rahmani, Shafira. "Siapa Pun Bisa Menjadi Pelaku Dan Korban Body Shaming!" Suara.Com, Desember 2019, https://yoursay.suara.com/news/20 19/12/31/130104/siapa-pun-bisamenjadi-pelaku-dan-korban-bodyshaming? page=all.

Rangkuti, Ahmad Nizar, and Fawziyah Tansyah Siregar. "Penanaman Sikap Amanah Peserta Didik Di Madrasah Tsanawiyah (MTs.) Swasta Syahbuddin Mustafa Nauli Kabupaten Padang Lawas Utara." Jurnal Pendidikan Agama Islam Al Thariqah 5.1 (2020): 1-9. DOI: https://doi.org/10.25299/althariqah.2020.vol5(1).3736

Sakinah. 'Ini Bukan Lelucon': Body Shaming, Citra Tubuh, Dampak dan Cara Mengatasinya." Jurnal Ilmiah Ilmu-Ilmu Sosial 1.1 (2018): 53-67.

Saleh, Sirajuddin. "Peran Lembaga Pendidikan dalam Membentuk Karakter Bangsa." Seminar Nasional Pendidikan Ilmu-Ilmu Sosial Membentuk Karakter Bangsa Dalam Rangka Daya Saing Global, (Universitas Negeri Makassar) (2016): 101-12.

Serni, et al. Dampak Body Shaming Siswa SMPN 17 Kendari Terhadap Perilaku Komunikasi. 1.2 (2020): 132-40.

Sukandar, Asep Ahmad, and Muhammad Hori. Pemikiran Pendidikan Islam: Sumbangan para Tokoh Pendidikan Islam Melalui Gagasan, Teori, dan Aplikasi. Bandung: Cendekia Press, 2020.

Shihab, M. Quraish. Tafsir Al-Mishbah: Pesan Kesan Dan Keserasian AlQur'an. Jakarta: Lentera Hati, 2012.

Sholeh, Sholeh. Asbabun Nuzul: Latar Belakang Historis Turunnya AyatAyat Alquran. Bandung: CV Penerbit Diponegoro, 2011.

Simanjuntak, Bungaran Antonius, and Soedjito Sosrodihardjo. Metode Penelitian Sosial (Edisi Revisi). Jakarta: Yayasan Pustaka Obor Indonesia, 2014.

Siregar, Nina Siti Salmaniah. Komunikasi Terapeutik Bernuansa Islami. Surabaya: Scopindo Media Pustaka, 2021.

Slee, Phillip T., and Grace Skrzypiec. "No More Bullying: An Analysis of Primary School Children's Drawings of School Bullying." Educational Psychology 36.8 (2016): 1487-1500. doi:10.1080/01443410.2015.10340 89.

Sugiarti. Kesatuan Dalam Keberagaman. Malang: Universitas Muhammadiyah Malang, 2020.

Sukenti, Desi, and Syahraini Tambak. 
"Developing Indonesian Language Learning Assessments:

Strengthening the Personal Competence and Islamic Psychosocial of Teachers." International Journal of Evaluation and Research in Education 9.4 (2020): 1079-1087.

Sukenti, Desi, and Syahraini Tambak. "Strengthening Islamic Psychosocial and Self-confidence in Develophing Student Thinking Creative." ICOSEEH 20194 (2019): 446-453.

Suradi. "Pembentukan Karakter Siswa melalui Penerapan Disiplin Tata Tertib Sekolah." Briliant: Jurnal Riset dan Konseptual 2.4 (2017): 522-533. doi:10.28926/briliant.v2i4.104.

Tambak, Syahraini, et al. "Internalization of Riau Malay Culture in Developing the Morals of Madrasah Ibtidaiyah Students." Al Ibtida: Jurnal Pendidikan Guru MI 7.1 (2020): 6984.

https://doi.org/10.24235/al.ibtida.s nj.v7i1.5954.

Tambak, Syahraini, and Desi Sukenti. "Pengembangan profesionalisme guru madrasah dengan penguatan konsep khalifah." Hayula: Indonesian Journal of Multidisciplinary Islamic Studies 4.1 (2020): 41-66. https://doi.org/10.21009/004.01.0.

Tambak, Syahraini, et al. "Profesionalisme Guru Madrasah: Internalisasi Nilai Islam Dalam Mengembangkan Akhlak Aktual Siswa." Jurnal Pendidikan Agama Islam Al Thariqah 5.2 (2020): 80-96. DOI: https://doi.org/10.25299/althariqah.2020.vol5(2).5885.

Tambak, Syahraini, and Desi Sukenti. "Strengthening Islamic behavior and Islamic psychosocial in developing professional madrasah teachers." Cakrawala Pendidikan: Jurnal Ilmiah Pendidikan 39.1 (2020): 65-78.

Tambak, Syahraini. "Pendidikan Etika Bergaul Islami Dalam Keluarga "Nilai Pendidikan Etika Berlaku Adil
Orangtua dengan Anak dalam Pergaulan Keluarga Perspektif Hadits"." Jurnal Pendidikan Agama Islam Al-Thariqah 4.1 (2019): 1-20. https://doi.org/10.25299/althariqah.2019.vol4(1).2910.

Tambak, Syahraini, et al. "Profesionalisme Guru Madrasah: Internalisasi Nilai Islam dalam Mengembangkan Akhlak Aktual Siswa." Jurnal Pendidikan Agama Islam Al-Thariqah 5.2 (2020): 79-96. https://doi.org/10.25299/althariqah.2020.vol5(2).5885.

Tambak, Syahraini, Amril M, Zuriatul Khairi, and Desi Sukenti. "Development of Madrasah Teacher Professionalism by Strengthening the Khalifah Concept and Islamic Psychosocial Perspective." International Conference on Islamic Education (ICIE 2018). Atlantis Press, 2018. https://doi.org/10.2991/icie18.2018.7.

Tambak, Syahraini. "Filsafat Idealisme dan Implikasinya pada Teori Pendidikan." Al-Hikmah 11.1 (2014): 61-75.

Tambak, Syahraini, M. Yusuf Ahmad, and Desi Sukenti. "Strengthening Emotional Intelligence in Developing the Madrasah Teachers' Professionalism (Penguatan Kecerdasan Emosional dalam Mengembangkan Profesionalisme Guru Madrasah)." Akademika 90.2 (2020). https://doi.org/10.17576/akad2020-9002-03.

Tambak, Syahraini. "Jihad Pendidikan: Konsep dan Upaya Memajukan Pendidikan Indonesia." AlHikmah 7.14 (2010): 1-15.

Watson, Lani. "Educating for Inquisitiveness: A Case against Exemplarism for Intellectual Character Education." Journal of Moral Education 48.3 (2019): 303315. 
DOI: 10.25299/al-thariqah.2021.vol6(1).6823

doi:10.1080/03057240.2019.15894 36.

Wulandari, Wijayanto Ari. Gosip Halal Vs Gosip Haram. Bandung: Pustaka Oasis, 2010.

Zuhri, Syaifuddin, dkk. Teori Komunikasi Massa dan Perubahan Masyarakat. Malang: PT Cita Intrans Selaras, 2020. 